\author{
Василь Денисюк, \\ кандидат філологічних наук, доцент \\ кафедри української мови та методики ії навчання \\ Уманського державного педагогічного університету імені Павла Тичини \\ ORCID: 0000-0002-6773-1380 \\ e-mail: dvv2812@ukr.net
}

\title{
РЕФЛЕКСІЯ УКРАЇНСЬКО-ПОЛЬСЬКИХ СТАРОЖИТНІХ ФРАЗЕОЛОГІЧНИХ ПАРАЛЕЛЕЙ
}

Стаття розпочинає дослідження украӥнсько-польських мовних контактів у царині діахронної фразеології. Автор звертає увагу на історичні та сочіальні чинники, щзо були передумовою контактів. На прикладі функиіювання фразеологізмів із компонентом горло / gardto в украӥнських і польських поетичних творах зроблено висновок про тотожність семантичної палітри та структурної організації таких стійких сполучень слів в обох мовах.

Ключові слова: мовні контакти, украӥнська мова, польська мова, фразеологізм, діахронія, поетичний дискурс.

\section{Denysiuk Wasyl. Refleksja ukraińsko-polskich starożytnych analogij frazeologicznych.}

Artykut zaczyna badanie ukraińsko-polskich kontaktów językowych w obszarze frazeologii diachronicznej. Autor zwraca uwage na czynniki historyczne oraz socjalne, będacych warunkami kontaktów. Na przykładzie funkcjonowania frazeologizmów z komponentem zорло / gardto w ukraińskich i polskich utworach poetyckich zrobiono wniosek o tożsamości palety semantycznej $i$ organizacji strukturalnej takich stałych połaczeń słów w obu językach.

Słowa kluczowe: kontakty językowe, język ukraiński, język polski, frazeologia diachronia, dyskurs poetycki.

\section{Denysiuk Vasyl. Reflection of Ukrainian-Polish of old phraseological parallels.}

The article deals with the urgent problem of linguistic contacts between the neighboring nationsUkrainians and Poles. Chronological boundaries are outlined in the $16^{\text {th }}-17^{\text {th }}$ centuries, when the influence of the Polish language on Ukrainian was most noticeable. The author draws attention to the historical and social factors that led to contacts. The purpose of the article was to find out the peculiarities of language contacts at the phraseological level, which is quite conservative from the point of view of grammar. The main task was to trace the reflection of phraseological units through the prism of individual perception of Ukrainians and Poles. As this is only our first article in this

field, we have limited our choice of phraseology with the zорло / gardlo component. The most commonly used are phraseological units that represent the semantic field of «die». The use of these phraseological units is motivated by extra-linguistic factors. Noteworthy is the fact that the phrase горло / gardto in phraseological units develops enantiosemic potencies. According to the analysis of Ukrainian and Polish poetic works, the semantic palette of such stable combinations of words is almost identical, the difference is observed only in the verbalization of devotion: Polish poets use phraseologism to depict devotion to secular ideals, while Ukrainian - religious. The structural organization of phraseological units in both languages is identical: they are formed by the model «noun + verb» and «verb + preposition + noun», sometimes complicated by attributive optional components (adjective, pronoun). We periodically record lexical variability. Some phraseological units are synonymous and antonymic.

Key words: language contacts, Ukrainian language, Polish language, phraseology, diachrony, poetic discourse. 
Постановка проблеми в загальному вигляді та її зв'язок із важливими науковими i практичними завданнями. Вивчення (взаємо)впливів і (взаємо)зв'язків сусідніх мов завжди викликає значні труднощі, оскільки не дозволяє з упевненістю визначити вектор поширення того чи того явища. Це стосується як фонетичного, так і інших рівнів мовної системи. Якщо фонетичний, словотвірний, граматичний рівні мають більш-менш узвичаєні погляди на явища їхніх мікросистем, то лексико-фразеологічна система залишається найбільш вразливою, такою, що ставить більше запитань, аніж має відповіді на них.

Українсько-польські мовні зв'язки тривають з часу заселення слов'янськими етносами своїх земель. Прикметно, що за такий період колись інтерферентні явища стали нормою в обох мовах, а поява нових відмінних рис спричинена контактуванням з неслов'янськими (для польської - це передусім німецька) та слов'янсько-азійськими (для української - це передусім російською - субстратом церковнослов'янської 3 азійськими) мовами. Тож опинившись у буферній зоні між Заходом і Сходом (не тільки лінгвальній!), українська й польська мови намагалися зберегти своєрідну слов'янську ідентичність через витворення українсько-польського / польсько-українського мовного простору. Звісно, таке може видатися малоймовірним, бо ж куди українсько-польському порубіжжю тягатися 3 українсько-білоруським, для якого вже узвичаєною є думка про спільну мову й для діловодства, i для побуту?! Такий стереотип у мовознавчій науці усталився через використання українцями та поляками різних графічних систем, що автоматично нівелюють усі намагання довести якщо не єдиний, то максимально близький мовний простір українськопольських земель у XIV-XVII ст. (ідеться, звісно, не про кресові території, що в межах мовного континууму виконували роль адаптаційного буфера, які в різні хронологічні періоди «відкривали ворота» наступу на лексичну систему). Такі періоди, власне, відкриваючи ворота одним запозиченням, закривали їх майже повністю для інших, що призводило до стирання власної ідентичности та зближення мови з иносусідніми, зокрема німецькою або російською. Цю специфіку коротко окреслив О. Ткаченко: «Мовні контакти обох мов, що сприяли певному їхньому зближенню при одночасному віддаленні української від східнослов'янських, а польської від західнослов'янських, стали для цих мов ще й джерелом семантичного i стилістичного збагачення завдяки збільшенню кількості лексичних синонімів. Питання українсько-польських мовних контактів досі глибоко не досліджено» [10, c. 770].

Цей висновок стосується, зокрема, і фразеологічного рівня. Аналіз емпіричної бази українського та польського мовознавства 3 проблем діахронної фразеології в контексті польсько-українських мовних контактів XVI-XVII ст. свідчить про велику лінгвістичну лакуну, оскільки такі праці торкаються переважно XIV-XV та XX ст. і виконані на матеріалі ділової документації (перша група) і художніх текстів (друга група). Для вивчення лексикофразеологічного фонду української й польської мов XIV-XVII ст. головним авторитетом слугують «Словник староукраїнської мови XIV-XV ст.», «Словник української мови XVI першої половини XVII ст.», «Історичний словник українського язика» та «Матеріали для словника писемної та книжної української мови XV-XVIII ст.» Є. Тимченка, «Słownik polszczyzny XVI w.», підготовлені різними колективами авторів в умовах різних суспільних трансформацій. Ці лексикографічні праці стають ніби першопочатком для досліджуваних номенів з відповідною ремаркою-закріпленням пол. чи укр. Зауважимо, що словникових статей із ремаркою укр. у польському словнику вкрай мало, що наштовхує на думку про єдиноможливий напрямок впливу - польська мова як джерело або посередниця. Вочевидь, тут спрацьовує соціальний чинник: якщо українські території входили до складу Речі Посполитої, то вплив міг бути тільки від офіційної на той час у державі мови - польської. А як внутрішня система мови? Чому її залишають осторонь? Її не існувало чи вона не могла чинити опору? Її лексичні одиниці не вступали в конкурентну боротьбу із запозиченнями? Де критерії визначення питомости чи першости? 
Аналіз основних досліджень і публікацій із зазначеної проблеми. Опертя на писемні чи рукописні пам'ятки не завжди виправдовує шлях появи тієї чи тієї лексеми в українській чи польській мові. Слушними є думки 3. Радули та А. Золтана про те, що часто в писемних пам'ятках української та німецької мов можна зафіксувати запозичення раніше, аніж воно засвідчене в пам'ятках мови-джерела [16, с. 73-74; 3, с. 137-138]. Причини цього криються у внутрішній політиці держави, зокрема тих її аспектах, що торкаються функціювання мови, освітньої системи. Демократизація суспільства, що хвилею йшла із Заходу, охопила й Річ Посполиту, що проявилося через заснування навчальних закладів зробити польський соціум освіченим, у перекладі Святого Письма живою мовою, у запозиченні літературних стилів і жанрів, та ін. Можемо констатувати, що Річ Посполита на XVI ст. отримала цілісну освітню систему підготовки громадян, де немаловагому роль відігравала й мовна. Про останню, зокрема, зауважимо, що не все було так просто, як може видатися на перший погляд. Залежність польської мови від латині як мови освіти, активні контакти 3 німецькою та чеською мовами, відсутність унормування спричинили витворення на польському мовному грунті своєрідного середньовічного суржику, яким послуговувалися не тільки в побуті, але й у літературі, що підтверджують проаналізовані поетичні тексти українських книжників XVIXVII ст., щедро пересипані польськими, латинськими, часто й німецькими словами. Вплив польської мови на українську в XVI ст. позитивно характеризує А. Лавриненко: «Факт максимального восприятия староукраинским языком польского (и - шире западнославянского) влияния следует рассматривать не как факт слабости или бедности (как считают некоторые лингвисты), а наоборот, как факт исключительной жизнеспособности, гибкости и огромного внутреннего (системного) потенциала, позволившего активно впитывать, творчески сегрегировать, перерабатывать и совершенствовать то, что было ему даровано лингвистической судьбой и сложившимися историческими обстоятельствами (даже при условии отсутствия таковых интенций со стороны языка-дарителя)» [5, с. 254].

Більш консервативне українське суспільство, незважаючи на помітні кроки в демократизації (відкриття освітніх закладів, переклад Святого Письма, книгодрукування, жанрово-стильове збагачення та ін.), на тлі мінімального поширення західного позитиву не могло витворити системи, подібної до польської, тому прогресивно налаштовані українці ставали частиною польського освітньо-культурного життя (напр., Якуб Гаватович, Касіян Сакович, Данило Братковський та інші діячі), докладаючи чималих зусиль для такого ж розвою українського суспільства, яке, проте, з другої половини XVII ст. поступово почало затухати через потрапляння українських лівобережних освітньо-культурних осередків, передусім Києва й Чернігова, під вплив Московії. І. Огієнко так про це зауважив: «Польські впливи з цього часу трохи спиняють свій войовничий характер, але наші письменники ще нерідко пишуть i по-польському, наприклад, Галятовський, Баранович (пор. «Лютня Аполлінова» 1671 р.) й ін.

3 1654-го року, коли Київ з Лівобережжям остаточно відійшов під Москву, майже на три столітті знову рветься соборність українського народу й його мови, - їх розвій з цього часу пішов відмінними шляхами: на Сході розпочався сильний вплив московський, а український захід був остаточно відданий на впливи польські. Там незабаром дійшло до того, що й по українських канцеляріях заведена була польська мова, бо писати мовою українською поляки заборонили» [8, с. 124].

Мовну ситуацію XVII ст. на українських теренах складно окреслити якимсь патетичним епітетом. Влучно про неї сказав В. Німчук: «найскомплікованіша в усій Свропі (якщо не в усьому світі)» [7, с. 1]. Багатоетнічна (відтак - i багатомовна) територія спочатку легко піддалася під латинь і польщизну, проте згодом частина освічених українців, переважно церковників, усвідомили ймовірну незворотність такого процесу, почали розвивати церковнослов'янську мову, додаючи до неї щораз більше живомовних рис. 3 цього приводу А. Лавриненко зауважує: «Польское влияние ускорило процессы так называемой «демократизации» формирующегося украинского языка литературного и отход от языка 
церковнославянского. При этом были разбужены интеллектуальные силы, пытающиеся этот язык (церковнославянский) сохранить и реформировать» [5, с. 254]. Думку А. Лавриненко про вплив української мови на польську в XIV-XV ст. та зворотний у наступні два століття заперечує Г. Вишневська, яка стверджує, що «... kontakty z bezpaństwowymi, ukrainnymi przestrzeniami ziem południowo-wschodnich nie wzbogacały naszego słownictwa dopóty, dopóki nie zaczęliśmy zamieniać je w wielkie magnackie fortuny (XVII/XVIII w.)» [18, c. 89].

Живомовність виразно починає простежуватися в Учительних євангеліях, «Требнику» П. Могили. Гарним продовженням рестайлінгу церковнослов'янщини на українських теренах слугують твори Й. Галятовського, А. Радивиловського, Д. Туптала та ін. Такі дії українських книжників знайшли підтримку на Сході, а через авторитет церкви було спущено ідею чужости польської мови. Тож можна говорити про те, що дії церковників мали подвійний стандарт: прагнучи просвітити українців, вони зовсім не приставали на польський шлях розвитку, оскільки це відбирало в них «шмат хліба». Натомість українському суспільству була запропонована полеміка про ополячення (мовне й релігійне) лише задля втримання своїх позицій у соціумі. Прикметно, що тогочасні польські церковні й культурні діячі зовсім не надавали ніякого значення аргументам Г. Смотрицького, І. Вишенського та інших полемістів, оскільки не вступали з тими в полеміку, а міркування П. Скарги, викладені у творах «O jedności Kościola Bożego pod jednym pasterzem», «O rządzie i jedności Kościola Bożego pod jednym pasterzem», «Synod Brzeski i jego obrona», $\epsilon$ радше поширеною українськими полемістами власною рецепцією текстів польського проповідника, аніж думкою українського загалу.

Релігійний чинник став тією домінантою, що відштовхнула українців від європейського шляху, залишивши за ними роль етносу, що попросився «під руку», а відтак на століття визначила статус залежного, який повинен виконувати вказівки старшого. 3 іншого боку, багато полонізмів залишилося в українській мові, продовживши в ній функціювати як синоніми до питомих лексем. До чого насправді могло призвести поширення польської мови на всі українські землі? Гадаємо, що перехід на польську мову в іiі варіанті XVIст. спровокував би розвиток на українських теренах не бi-, а полілінгвального суржику, такого, яким, власне, була тогочасна польська літературна мова.

Початок XXI ст. ознаменував в Україні новий вибух досліджень українсько-польських мовних контактів. Наукові розвідки цій проблемі присвятили С. Гриценко [1], В. Мойсієнко [6], В. Титаренко [9] та інші мовознавці. Прикметно, що більшість студій виконано на матеріалі писемних пам'яток та з урахуванням мовної ситуації, що склалася на українських теренах у XVI-XVII ст. Окремі дослідження торкаються українсько-польських фразеологічних паралелей (В. Денисюк [2], Т. Космеда [4] та ін.). Нашу увагу привернула тогочасна українська й польська поезія. Вибір саме такого різновиду художнього дискурсу дозволив 3 більшою імовірністю визначити трансформаційні аспекти запозичених фразеологічних одиниць, оскільки поетичні твори змушують авторів послуговуватися різними прийомами введення стійких сполучень слів у мовну палітру тексту, моделювати фразеологізм залежно від енциклопедичности й римових уподобань автора й водночас із метою інтелектуалізації читача.

Зауважимо, що польська діахронна фразеологія у своєму арсеналі має тільки лаконічні зауваження про стійкі сполучення слів у мові творів поетів XVI-XVII ст., підкріплюючи такі зауваги коротким переліком фразеологізмів. Зрідка в коментарях подибуємо вказівку на можливе запозичення з української мови як джерела чи посередниці. Зокрема, С. Роспонд, аналізуючи мову творів Я. Кохановського, зазначив: «Od połowy XVI w. mnożyły się te zapożyczenia również potoczne, komunikatywne. W poezji Kochanowskiego służyć one będą przeważnie stylizacji, pełniąc funkcję indywidualizującą. W czasie pobytu na dworach magnatów małopolskich Tarnowskiego, Tęczyńskiego, Firleja zapoznał się poeta z językiem ukraińskiem. Wplatał nieraz do swoich utworów żywcem przejęte z tego języka idiomatyzmy: łacno durować, kiedy przystępuje, Szachy w. 554 (przysł. ukr. dobre duryty, koty prystupuje (por. H. Morsztyn 
„Światowa rozkosz”: łacno durować, koli przystępuje). <..> Ponieważ ukraińskie wpływy językowe bliższe były poecie niż papierowe czechizmy [17, с. 275]. Г. Вишневська мові творів Берната з Любліна присвятила монографію, у якій подала значну кількість фразеологічних зворотів таких семантичних полів, як mierność, czcienie, pożywienie, zdrowie / choroba, mówienie та ін. [18, с. 100-183]. Щоправда, сумнівним видається тлумачення дослідницею сполучень слів bił kramarz osła kijem, pachnie albo śmierdzi z gardta та ін. як стійких, оскільки контекстуальний аналіз засвідчує, що ці одиниці вжито з прямим значенням, відтак вони реалізують виключно номінативну функцію без будь-яких зсувів у семантичній структурі всього сполучення слів.

Окреслення невирішених питань, порушених у статті. Наша розвідка $є$ початком вивчення українсько-польських старожитніх фразеологічних паралелей на матеріалі поетичних творів. Привертають увагу концентри, яким присвячені поезії: античність, Святе Письмо, війна як соціальний конфлікт і як призвідця загибелі багатьох людей, життєві перипетії, до того ж крізь призму перших двох автори намагаються «авторитетно» переконати людство загалом і кожного зокрема в істинности й непорушности давніх догм. Чи не найпопулярнішим для польських та українських поетів стає образ смерти, поданої в позитивно й негативно конотованих аспектах. Зокрема, в аналізованих поезіях подибуємо фразеологізми 3 компонентом gardło / горло, що, поєднуючись із дієсловом, розвиває енантіосемійні потенції, реалізуючи семантику смерти чи життя. Аналізовані поезії засвідчують уживання фразеологічних одиниць із лексемою gardło / горло для репрезентації широкої палітри значень. Одразу зауважимо, що для правильного визначення сполучення слів як стійкого та з'ясування його семантики ми послуговувалися контекстуальним аналізом, а також дискурс-аналізом, що дозволило окреслити основний наратив уживання таких фразеологізмів: це контексти, у яких автори описують передусім події війни, а також інші соціальні конфліктні ситуації. Оскільки середньовічна Річ Посполита, як і Україна, утомилася від воєн, поезія дещо змінила тематичне коло: польські автори пишуть інтимну лірику, інколи надаючи віршам баладного обрамлення, часто висміюють суспільні негаразди; українські книжники зосереджують увагу переважно на проблемах духовности, по-різному тлумачать біблійні істини, розвивають геральдичну та панегіричну поезію. Тож констатуємо, що фразеологізми з компонентом gardto / горло були нечастими гостями в поезіях.

Формулювання мети i завдань статті. Метою статті $\epsilon$ з'ясування корпусу фразеологізмів із лексемою горло / gardto та їх компаративний структурно-семантичний аналіз, для чого необхідно було опрацювати емпіричну базу, методом суцільної вибірки виписати з поетичних текстів українських та польських авторів фразеологічні одиниці із задекларованим компонентом, класифікувати їх за структурним та семантичним параметрами, простежити варіативність фразеологізмів.

Виклад основного матеріалу 3 обгрунтуванням отриманих наукових результатів. Польські поетичні твори XVI-XVII ст. свідчать про широку палітру значень фразеологічних одиниць із лексемою gardto, зокрема вони реалізують семантику:

померти. Це семантичне поле утворюють одиниці на позначення різних аспектів смерти. Позитивну конотацію отримують фразеологізми, що вказують на смерть як наслідок прояву відваги, мужности в бою, напр.: Tuśmy się mężnie prze ojczyznę bili / I na ostatek gardtla polożyli [12, c. 34]; Karać było Tatarów, pewnie by was byli / Kozacy na Bosforze nigdy nie szkodzili, / Których herstowie zawsze skoro się wracali, / Takiej swojej odwagi gardlem przyptacali [15, c. 169]. Семантично тотожним постає фразеологізм gardto dać, що репрезентує усвідомлене рішення козаків загинути, аніж потрапити в полон, напр.: Bo gdy $w$ on chrust przed nasza szabla uchodzacy / Wpadna, i nie zastawszy powiąanych koni, / Niechybnie by musieli gardlo dać pogoni $[15$, с. 173]. Дещо інший відтінок має сполучення слів gardła pozbawity, оскільки, 3 одного боку, йому властива нейтральність, де воно виконує звичну номінативну функцію, а 3 іншого - указує на міжстильові зв'язки, тому що головною цариною його побутування був діловий стиль. В епітафіï «Nagrobek Pawłowi Chmielowskiemu» Я. Кохановський 
послуговується цим фразеологізмом зі стилістичною метою, акцентуючи увагу на не завжди правильних рішеннях представників Феміди, напр.: Wiatry z pótnocnym morzem na mie się zmówity, / Aby mię, niewinnego, gardła pozbawily [13, с.41]. Семантичне поле «померти» розширюють одиниці, що репрезентують уживання лексеми gardło «життя» в складі іменниково-дієслівних сполучень зі значенням «вид покарання шляхом відрубування голови». Такими одиницями послуговуються польські поети для описування протиправних, на їхню думку, дій козаків, за що останні заслуговують тільки на страту, напр.: Ponieważ nigdy złego złym pozbyć nie wadzi, / Żeby kilku Kozaków, którzy zarobili / Na gardlo, a jeżeli tacy by nie byli / W obozie $i$ w Kamieńcu, choć Ruś prosta będzie, / Byle dosyć uczynić Osmanowej zrzędzie [15, с. 231]. Сема 'померти' актуалізована й у фразеологізмі gardłem odkupyć, що синкретизує в собі сему 'розплата'. Я. Кохановський, використовуючи прийом антитези, послуговується стійким сполученням слів для змалювання психічного стану Кристини усвідомлення своєї гріховної поведінки, напр.: Mało dalej król wzajem Margrabstwo wojuje, / A cna Krystyna gardlem cześć swa odkupuje / Dobrowolnie [13, c. 121];

жстии. Спорадично в польській поезії представлені фразеологізми, що дозволяють виокремити в семантичному наборі стійких сполучень слів із лексемою gardło значення «жити». Контекст засвідчує, що фразеологізм уступає в антонімічні відношення 3 одиницями, що репрезентують семантику «померти через відрубування голови», напр.: A sam nędznik, gdy gardlo z hańbq swa uprosit, / Za wielowladne berło szkolna rózgę nosit [14, c. 42-43];

бути відданим, готовим до самопожертви. Номен gardło як один з головних лексичних репрезентантів поняття «життя» в складі фразеологізму реалізує семантику готовности до найвищого вияву самопожертви - віддати життя за свою країну. Проте загальний контекст стирає позитивну конотацію фразеологізму, адже автор оповідає про боягузтво, зраду людей, які попервах задекларували себе відданими представниками свого народу, напр.: I ubezpieczyliście naprzód dzieci swoje, / Że, mając wieczność albo dożywocie troje, / Moga się poczciwymi stużbami nie bawić. / A którzy chętni byli gardl swoich nadstawić / Ku postudze koronnej, nie będa snać chcieli, / Boście je do wszytkiego dawno ubieżeli [13, c. 101];

перешкоджати, ставати ненависним комусь. Ці фразеологізми також обертаються навколо семантичного центру «життя», тому видається логічним, що потрапляння чогось у горло асоціюється 3 перешкоджанням нормальному функціюванню організму, відтак і нормальному життю загалом, напр.: Bo Brodawka, kozacki wódz chocimskiej drogi, / Idac bez wszelkiej sprawy, bez wszelkiej przestrogi, / Wlazł Turkom $\boldsymbol{w}$ samo gardlo, gdzie albo umierać, / Albo ти trzeba było środkiem się przedzierać / Bisurmańskich taborów [15, с. 87]. Вихід у ширший стильовий простір фразеологізмів із лексемою gardło розвиває значення «ставати ненависним комусь», напр.: Drudzy zmyja swoja krwia krew zdradnie rozlang / Lacka $w$ stołecznym mieście, kościa w gardle stana / Łupy im niezadtugo, równie bez litości / Oddadza okrucieństwo, wzgardę, zelżywości [14, c. 63-64].

Привертає увагу структурна організація засвідчених фразеологізмів: двокомпонентні сполучення мають закріплений порядок складників - іменник + дієслово (звісно, можуть бути розширеними за рахунок факультативних компонентів, які, проте, не впливають на порядок основних), тоді як трикомпонентні й більше демонструють незакріплений порядок складників.

В українських поезіях фразеологізмів 3 компонентом горло фіксуємо небагато, що пов'язано з іншим тематичним спрямуванням творів. Проте це зовсім не позначилося на семантичній палітрі, яку реалізували стійкі сполучення слів з лексемою горло. Зокрема, фразеологізми, котрі репрезентують семантичне поле «померти», $є$ виразниками тих же конотацій, що й у тогочасній польській мові, напр.: Розмайте д бток невинных мордуючи, / Христа межи ними, шаленець, шпикгуючи, / Невинняток, котрыи бы му зад блали, / За щзо бы слушне горла свой подавали [11, Беринда П.]; Внет мещзан защных в колоду посажано, / A найубогшых в темнииу загнано, / Абы росправы до часу чекаль / И горло дали [11, М. Н., 
Замкненя]; Хотђль духовныли в тую справу вложыти / $A$ на их здоровя горло своє положыти, / Але им слова на то рещъь не дано, / Преч им казано [11, М. Н., Замкненя].

Дещо іншу конотацію отримує сема 'покарання'. А. Скульський послуговується їі вербальним репрезентантом для змалювання погорди, коли люди почали скаржитися на Христа й просити йому смерти, напр.: $О$ земле, якож-єсь их не загорнула / И знагла ораз живо всъх не полкнула? / Що ж теды за скарги на пана вносили / И на горло пред судом дужо просили [11, Скульський А., Димигоріа трену утерпъня муки Христовы].

Лексичну варіативність засвідчує фразеологізм горкостю в горль ставати, що символізує стосунки неприязни між людьми, напр.: На карк му, о сыну, дужо наступаєш / И горкостю ся єму в горль ставаєш [11, Скульський А., Лямент матки Збавителевы над Сыном єи].

Якщо в польській поезії спостерігаємо залучення фразеологізмів з компонентом gardto для репрезентації відданости світським ідеалам, то в поетичних рядках українських книжників таке стійке сполучення слів характеризує відданість релігійним ідеям, напр.: Єсли люде поганскыи того перестер бгалы, / Абы учтивос[ть] своим Богом выряжаль, / Як ся о их славу заставляли менжне, / Боронячы их учтивости аж до горл потенжне [11, М. Н., Лямент].

Структурний аспект виявляє повну тотожність українських фразеологічних одиниць із польськими.

Висновки та перспективи подальших досліджень. Отже, невеликий фрагмент фразеологічної системи української та польської мов свідчить про використання однакових стійких сполучень слів для номінації однотипних явищ. Кількісно різну репрезентацію фразеологізмів можна пояснити тільки з позицій соціальних чинників, головними 3 яких були освіта й книгодрукування. Зафіксовані фразеологізми демонструють однакову семантичну палітру з незначними конотативними відмінностями, а їхня структура повністю збігається. Спорадично засвідчено лексичну варіативність. Ця розвідка є лише початком компаративних діахронних фразеологічних досліджень, що дозволять з'ясувати спільне й відмінне у фразеологічній картині світу двох слов'янських народів-сусідів як результат середньовічної міжкультурної взаємодії.

\section{Список використаних джерел та літератури}

1. Гриценко С. Роль польських запозичень у формуванні мовної картини світу українців (на матеріалі українських писемних пам'яток XVI-XVII ст.). Studia Ukrainica Poznaniensia. 2015. Vol. III. S. 8796.

2. Денисюк В. В. Польський вплив на формування фразеологічної системи української мови XVIXVIII ст. Rozdroża. Polsko-ukraiński dyskurs humanistyczny / red. R. Dymczyk, I. Krywoszeja, N. Morawiec. Poznań - Humań - Częstochowa, 2013. C. 132-138.

3. Золтан А. Фразеологизм ломать голову в сравнительном аспекте (по поводу выхода нового издания книги «Русская фразеология. Историко-этимологический словарь» под ред. В. М. Мокиенко). Русская, украинская и русинская лексикология и лексикография. Сборник статей памяти профессора Иштвана Удвари. - Orosz, ukrán és ruszin lexikológia és lexikográfia. Tanulmánykötet Udvari István professzor emlékére. Nyíregyháza : Krúdy, 2006. C. 133-143.

4. Космеда Т. Українсько-польські паралелі в системі фразеологічних біблеїзмів. Acta PolonoRuthenica. 2019. XXIV/2. C. 139-150.

5. Лавриненко А. Польское языковое влияние в староукраинской деловой письменности XIV-XV веков. Rzeszów : Wydawnictwo Uniwersytetu Rzeszowskiego, 2008. 326 c.

6. Мойсієнко В. М. Мовна ситуація в Україні у першій половині XVII ст. та ії відбиття у практиці ведення актових книг міських канцелярій. Украӥна - Польща: мовно-культурологічний діалог слов'янства. Київські полоністичні студії. Зб. наук. праць. 2006. Вип. 8. С. 83-102.

7. Німчук В. Конфесійне питання і українська мова кінця XVI - початку XVII ст. Берестейська унія $i$ українська культура ХVII століття. Львів : Місіонер, 1996. С. 1-18.

8. Огієнко І. Історія української літературної мови. Київ : Либідь, 1995. 296 с.

9. Титаренко В. Мовна ситуація на північноукраїнських землях у XVI-XVII ст. Украӥнська полоністика. 2008. Вип. 5. С. 153-164. 
Василь Денисюк. Рефлексія украӥнсько-польських старожитніх фразеологічних паралелей

10. Ткаченко О. Б. Українсько-польські мовні контакти. Українська мова. Енциклопедія / редкол.: В. М. Русанівський, О. О. Тараненко (співголови), М. П. Зяблюк та ін. Київ : Вид-во «Українська енциклопедія ім. М. П. Бажана», 2007. С. 770.

11. Украӥнська поезія кіния XVI - початку XVII cm.; Украӥнська поезія середини XVII cm. URL: http://litopys.org.ua (дата звернення: 26.09.2019).

12. Kochanowski J. Utwory wybrane. Białystok : Wydawnictwo «Łuk», 1993. $208 \mathrm{~s}$.

13. Kochanowski J. Wybór poezji. Sycyna : Stowarzyszenie Oświatowe Sycyna, 2000. 184 s.

14. Podhorecki J. D. Nemezis Kraju Pótnocnego / opracowała Aleksandra Oszczęda. Warszawa : Wydawnictwo Neriton, 2010. $110 \mathrm{~s}$.

15.Potocki W. Wojna chocimska. URL: http://wolnelektury.pl/katalog/lektura/wojna-chocimska (дата звернення: 15.10.2019).

16. Ráduly Z. Język ukraiński jako dodatkowe źródło polskiej leksykologii historycznej. Polono-Hungarica. Nyelvészet. Irodalom. Történelem. Kultúrtörténet. Budapest: ELTE BTK Lengyel Filológiai Tanszék Lengyel Tájékoztató és Kulturális Központ, 1992. S. 72-76.

17. Rospond S. Język i artyzm językowy Jana Kochanowskiego. Wrocław, 1961. 342 s.

18. Wiśniewska H. Renesansowa nowoczesność w przypowieściach, czyli bajkach Biernata z Lublina (ok. 1456 - ok. 1529). Lublin : Wydawnictwo Uniwersytetu Marii Curie-Skłodowskiej, 2015. 213 s.

\section{References (translated \& transliterated)}

1. Hrytsenko, S. (2015). Rol polskykh zapozychen u formuvanni movnoi kartyny svitu ukraintsiv (na materiali ukrainskykh pysemnykh pamiatok XVI-XVII st.) [The role of Polish borrowings in shaping the Ukrainians' language map of the world (on the material of Ukrainian literature sources of XVI-XVII centuries)]. Studia Ukrainica Poznaniensia, Vol. III, 87-96 [in Ukrainian].

2. Denysiuk, V. V. (2013). Polskyi vplyv na formuvannia frazeologichnoi systemy ukrainskoi movy XVIXVIII st. [Polish influence on the formation of the phraseological system of the Ukrainian language of XVI-XVII centuries]. Rozdroża. Polsko-ukraiński dyskurs humanistyczny - Crossroads. Polish-Ukrainian Humanistic Discourse. R. Dymczyk, I. Krywoszeja, N. Morawiec (Ed.). Poznań - Humań - Częstochowa, 132-138 [in Ukrainian].

3. Zoltan, A. (2006). Frazeologizm lomat golovu v sravnitelnom aspekte (po povodu vykhoda novogo izdaniya knigi «Russkaya frazeologiya. Istoriko-etimologicheskiy slovar» pod red. V. M. Mokiyenko) [Phraseologism ломать голову in a comparative aspect (regarding the release of a new edition of the book «Russian Phraseology. Historical and Etymological Dictionary» edited by V. M. Mokienko)]. Russkaya, ukrainskaya i rusinskaya leksikologiya i leksikografiya. Sbornik statey pamyati professora Ishtvana Udvari. Nyíregyháza: Krúdy, 133-143 [in Russian].

4. Kosmeda, T. (2019).Ukrainsko-polski paraleli v systemi frazeolohichnykh bibleizmiv [Ukrainian-Polish parallels in a system of phraseological bibleisms]. Acta Polono-Ruthenica, XXIV/2, 139-150 [in Ukrainian].

5. Lavrinenko, A. (2008). Polskoye yazykovoye vliyaniye v staroukrainskoy delovoy pismennosti XIV-XV vekov [Polish linguistic influence in the old Ukrainian business writing of the XIV-XV centuries]. Rzeszów: Wydawnictwo Uniwersytetu Rzeszowskiego [in Russian].

6. Moisiyenko, V. M. (2006). Movna sytuatsiia v Ukraini u pershii polovuni XVII st. ta yii vidbyttia u praktytsi vedennia aktovykh knyh miskykh kantseliarii [The language situation in Ukraine in the first half of the XVII century and its reflection in the practice of keeping records of city offices]. Ukraina Polshcha: movno-kulturolohichnyi dialoh slovianstwa. Kyivski polonistychni studii. Zb. nauk. prats, issue 8, 83-102 [in Ukrainian].

7. Nimchuk, V. (1996). Konfesiine pytannia i ukrainska mova kintsia XVI - pochatku XVII st. [The confessional question and the Ukrainian language of the late XVI - early XVII centuries]. Beresteiska uniia i ukrainska kultura XVII stolittia. Lviv: Misioner, 1-18 [in Ukrainian].

8. Ohiienko, I. (1995). Istoriia ukrainskoi literaturnoi movy [History of Ukrainian literary language]. Kyiv: Lybid [in Ukrainian].

9. Tytarenko, V. (2008). Movna sytuatsiia na pivnichnoukrainskykh zemliakh u XVI-XVII st. [Language situation in North Ukrainian lands in XVI-XVII centuries]. Ukrainska polonistyka - Ukrainian Polonistics, issue 5, 153-164 [in Ukrainian].

10. Tkachenko, O. B. (2007). Ukrainsko-polski movni kontakty [Ukrainian-Polish language contacts]. Ukrainska mova. Entsyklopediia. V. M. Rusanivskyi, O. O. Taranenko, M. P. Ziabliuk ta in. (Ed.). Kyiv: Vyd-vo «Ukrainska entsyklopediia im. M. P. Bazhana» [in Ukrainian]. 
11. Ukrainska poeziia kintsia XVI - pochatku XVII st.; Ukrainska poeziia seredyny XVII st. [Ukrainian poetry of the late XVI - erly XVII centuries; Ukrainian poetry of the middle of the XVII century]. Retrieved from http://litopys.org.ua [in Ukrainian].

12. Kochanowski, J. (1993). Utwory wybrane [Selected works]. Białystok: Wydawnictwo «Łuk» [in Polish].

13. Kochanowski, J. (2000). Wybór poezji [Selected poetry]. Sycyna: Stowarzyszenie Oświatowe Sycyna [in Polish].

14.Podhorecki, J. D. (2010). Nemezis Kraju Pótnocnego [Nemesis of the Northern Territory]. A. Oszczęda (oprac.). Warszawa: Wydawnictwo Neriton [in Polish].

15.Potocki, W. Wojna chocimska [The Khotyn War]. Retrieved from http http://wolnelektury.pl/katalog/lektura/wojna-chocimska [in Polish].

16. Ráduly, Z. (1992). Język ukraiński jako dodatkowe źródło polskiej leksykologii historycznej [Ukrainian as an additional source of Polish historical lexicology]. Polono-Hungarica. Nyelvészet. Történelem. Kultúrtörténet. Budapest: ELTE BTK Lengyel Filológiai Tanszék - Lengyel Tájékoztató és Kulturális Központ, $72-76$ [in Polish].

17. Rospond, S. (1961). Język $i$ artyzm językowy Jana Kochanowskiego [Language and language talent of Jan Kochanovsky]. Wrocław [in Polish].

18. Wiśniewska, H. (2015). Renesansowa nowoczesność w przypowieściach, czyli bajkach Biernata z Lublina (ok. 1456 - ok. 1529) [The Renaissance New Reality in the Parables, or the Bernat Fables of Lublin (ca. 1456 - ca. 1529)]. Lublin: Wydawnictwo Uniwersytetu Marii Curie-Skłodowskiej [in Polish].

Прийнято до друку 22.11.2019 року 